\title{
КАЧЕСТВО МУЖСКОГО ГАМЕТОФИТА ГИБРИДОВ ТОМАТА В УСЛОВИЯХ ПОВЫШЕННОЙ ТЕМПЕРАТУРЫ
}

\author{
Анточ Л.П., Салтанович Т.И. \\ Институт генетики, физиологии и защиты растений, Кишинэу, Республика Молдова \\ e-mail: ludmila.antoci@igfpp.md
}

\begin{abstract}
The aim of the research was to study the effect of high temperature on the variability of male gametophyte traits in hybrid $\mathrm{F}_{5}$ populations of tomato.

Thus, it was found that the high temperature has a significant effect on the variability of the male gametophyte characteristics of tomato hybrids. For the combinations under study, it was revealed that the temperature factor and genotype are the main sources of variability of the male gametophyte traits against the background of elevated temperature. As a result of the experiments, the two most heatresistant tomato genotypes were identified.
\end{abstract}

Key words: pollen, temperature, breeding, resistance, tomato, genotypes, tomato, hybrid

\section{Введение}

В условиях Молдовы продуктивность генотипов томата, как и многих других культур, лимитирована недостаточной адаптивностью к стрессовым условиям внешней среды. В этой связи важное значение приобретает устойчивость растений к действию высоких температур на этапах репродуктивного развития. Известно, что многие генотипы томата недостаточно термоустойчивы, что в больщинстве случаев приводит к ухудшению завязывания плодов. В этой связи оценка и отбор генотипов томатов, устойчивых к высокой температуре, является важным направлением, позволяющим снизить негативные последствия действия окружающей среды [1]. Известно, что действие высокой температуры вызывает морфологические, физиологические, биохимические и молекулярные изменения растений, существенно влияющие на их рост и развитие как на вегетативных, так и репродуктивных стадиях [2]. Высокая температура оказывает также значительное влияние и на качество пыльцы, уменьшая ее жизнеспособность, что в итоге сказывается и на завязывании плодов. Показано, что возникающая вариабильность жизнеспособности пыльцы связана с изменениями уровня и состава нескольких групп метаболитов, которые играют важную роль в развитии пыльцы, способствуют ее питанию или обеспечивают защиту от стрессов окружающей среды [1]. Следует отметить, что селекция на устойчивость к высокой температуре затруднена из-за низкой наследуемости этого признака $[3,4]$. Существует мнение, что успех селекции по этому признаку определяется эффективностью идентификации генотипов, характеристиками компонентов, лежащих в основе завязывания плодов на фоне теплового стресса, а также информацией об их генетической архитектуре (генетической основе и вариационных свойствах) как на вегетативной, так и на репродуктивной стадиях [5].

Учитывая то, что селекция растений на устойивость к абиотическим факторам предполагает оценку признаков с высокой чувствительностью, а также недорогих методов определения возникающей изменчивости, для этих целей могут быть эффективно применены методы гаметной селекции. При этом скрининг по жизнеспособности пыльцы особенно важен, так как результаты многих исследований обнаружили его сильную положительную связь с завязыванием плодов [6-8].

Цель проведенных исследований состояла в изучении влияния повышенной температуры на изменчивость признаков мужского гаметофита гибридных популяций $\mathrm{F}_{5}$ томата.

\section{Материалы и методы}

Для проведения исследований были использованы 8 внутривидовых гибридных комбинаций F5 томата: 1 - Мэри Гратифулли (М.Г.) х Томиш, 2 - Мэри Гратифулли (М.Г.) х Престиж, 3 -Мэри Гратифулли (М.Г.) х Юбиляр, 4 - Мэри Гратифулли (М.Г.) х Эльвира, 5 - Мэри Гратифулли х 
Михаэла (М.Г.), 6 - Венец х Эльвира, 7 -Венец х Михаэла, 8 -Викторина х Михаэла. Растения культивировали на экспериментальном участке по общепринятой для томатов методике. На стадии цветения собирали полностью раскрытые цветки, подсушивали пыльники и выделяли пыльцу, которую помещали в термостат с температурным режимом $40^{\circ} \mathrm{C}$ и экспозицией прогревания 2 и 4 часа (опыт). В контроле пыльца находилась при оптимальной температуре $27^{\circ} \mathrm{C}$. По истечении указанного времени пыльцу контрольного и опытных вариантов высевали на предметные стекла в каплю питательной среды и проращивали в течении 3-х часов при температуре $28^{\circ} \mathrm{C}$. Под микроскопом подсчитывали число проросших и непроросших пыльцевых зерен (не менее 500 штук) по каждому генотипу. Жизнеспособность пыльцы (ЖП) определяли по соотношению проросших к общему числу изученных пыльцевых зерен и выражали в процентах. Под микроскопом также измеряли и длину пыльцевых трубок (ПТ) в условных единицах (усл.ед.). На основании полученных данных вычисляли устойчивость пыльцы (УП), как соотношение показателей жизнеспособности пыльцы в опыте к контролю и выражали в процентах, а также определяли устойчивость пыльцевых трубок (ПТ) как соотношение их длины в опыте к контролю в процентах. Статистическую обработку результатов проводили с использованием методов суммарной статистики, а также методом многофакторного дисперсионного анализа с использованием программ STATGRAPHICS v.5.1 и Exel-2013.

\section{Результаты и обсуждение}

При проведении исследований по изучению реакции мужского гаметофита к действию температурного фактора установлено, что фон повышенной температуры оказывал дифференцированное влияние на вариабильность анализируемых признаков пыльцы томата.

Установлено, что в зависимости от комбинации скрещивания значения жизнеспособности пыльцы в контрольных вариантах были довольно высокими и варьировали в пределах $62,5 \ldots 77,5 \%$. Проведенный анализ показал, что в результате прогревания пыльцевых зерен жизнеспособность пыльцы в опытных вариантах была ниже контрольных значений в среднем по всем генотипам в 2,3 ...3,1 раза в зависимости от экспозиции. Одновременно уменьшались и размеры пыльцевых трубок, их длина в опытных вариантах была в среднем меньше, чем в контроле в $1,3 \ldots 1,7$ раза (рис.1).

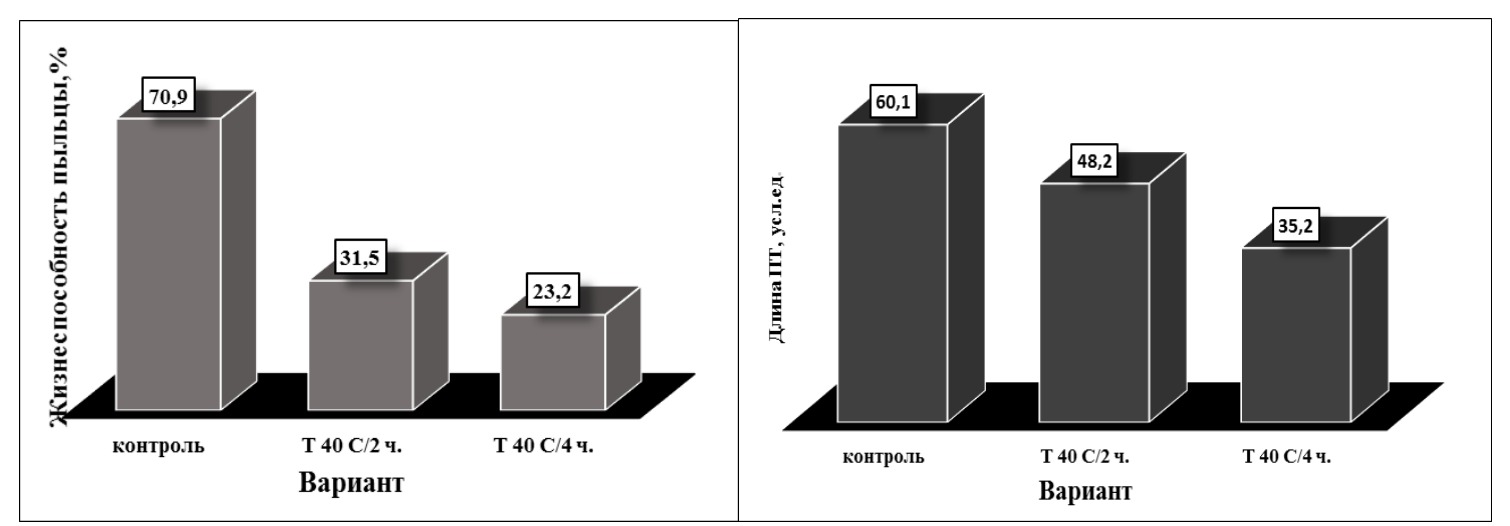

Рис.1. Влияние температуры на изменение признаков мужского гаметофита.

Однако, следует отметить, что реакция генотипов на температуру была дифференцировнной. Так, установлено, что наиболее сильно на прогревание реагировали пыльцевые зерна гибрида М.Г.х Эльвира, его жизнеспособость в результате 2-х или 4-х часового прогревания уменьшалась в 4,3 и 4,8 раза соответственно. У этого же генотипа в опытных вариантах формировались и гораздо более короткие пыльцевые трубки по сравнению с контролем. Одновременно были выявлены 3 гибридные комбинации (F5 М.Г. х Томиш, М.Г. х Юбиляр, Викторина х Михаэла), у которых с увеличением экспозиции прогревания пыльцевых зерен качество пыльцы не изменялось, что может свидельствовать о том, что в условиях продолжительного влияния высокой температуры у этих генотипов жизнеспообность пыльцы будет стабильной. Кроме того, полученные результаты показали, что увеличение времени 
прогрева пыльцы у двух генотипов (F5.Г. х Михаэла, Венец х Эльвира) приводило к снижению ее жизнеспособности пыльцы вдвое.

Для определения доли влияния факторов, детерминирующих выявленную изменчивость мужского гаметофита в результате его прогревания, проведена обработка полученных результатов методом многофакторного дисперсионного анализа. Установлено, что выявленная вариабельность достоверно $(\mathrm{P}<0,001)$ определяется генотипом, температурным фактором и их взаимодействием. В общей структуре изменчивости признаков жизнеспособность пыльцы и устойчивость пыльцевых трубок установлена решающая доля влияния температурного фактора 67,6 и 72,0\%, тогда как сила действия генотипа была гораздо слабее и составляла 25,0 и 22,0\%, а взаимодействие этих факторов было равно 7,4 и 6,0\% соответственно (рис.2).

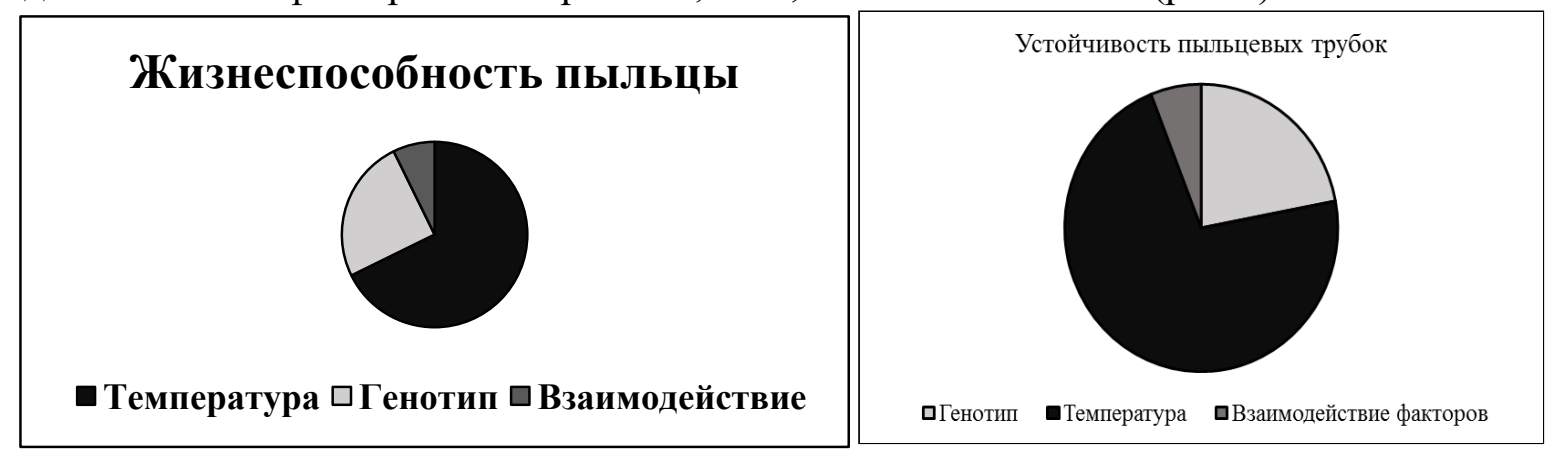

Рис.2. Основные источники изменчивости признаков мужского гаметофита томата.

Как показали полученные результаты, по средним значениям жизнеспособности пыльцы на всех фонах выделились 3 гибридные комбинации F5 (Викторина х Михаэла, М.Г.х Михаэла, Венец х Михаэла), у которых значения этого показателя состаляли 45,2...49,0\%. У остальных гибридов значения этого признака были более низкими. Различались генотипы и по размерам пыльцевых трубок, так у 3-х гибридов (М.Г. х Томиш, М.Г. х Престиж и М.Г. х Эльвира) формировались пыльцевые трубки самых больших размеров, что может свидетеьствовать о высокой скорости их прорастания и роста.

Таблица. Характеристика гибридов томата по признакам мужского гаметофита

\begin{tabular}{|l|c|c|c|c|}
\hline $\begin{array}{c}\text { Гибридные комбинации } \\
\mathrm{F}_{5}\end{array}$ & $\begin{array}{c}\text { Жизнеспо- } \\
\text { собность } \\
\text { пыльцы, \% }\end{array}$ & $\begin{array}{c}\text { Термо- } \\
\text { устойчивость } \\
\text { пыльцы, \% }\end{array}$ & $\begin{array}{c}\text { Длина } \\
\text { пыльцевых } \\
\text { трубок } \\
\text { (усл.ед.) }\end{array}$ & $\begin{array}{c}\text { Термо- } \\
\text { устойчивость } \\
\text { пыльцевых } \\
\text { трубок, \% }\end{array}$ \\
\hline М.Г.х Томиш & 38,48 & 42,40 & 52,87 & 83,78 \\
\hline М.Г.х Престиж & 36,74 & 37,83 & 51,83 & 64,59 \\
\hline М.Г. Ю Юбиляр & 39,06 & 40,0 & 48,58 & 68,65 \\
\hline М.Г. х Эльвира & 36,19 & 23,24 & 50,51 & 59,07 \\
\hline М.Г. х Михаэла & 46,45 & 55,34 & 45,00 & 65,06 \\
\hline Венец х Эльвира & 43,90 & 45,56 & 44,22 & 80,26 \\
\hline Венец х Михаэла & 49,00 & 69,50 & 40,55 & 67,74 \\
\hline Викторинах Михаэла & 45,21 & 42,00 & 49,00 & 75,29 \\
\hline НСР & $\mathbf{1 , 6 3}$ & $\mathbf{2 , 0 7}$ & $\mathbf{1 , 5 3}$ & $\mathbf{1 . 8 5}$ \\
\hline
\end{tabular}

Учитывая то, что информация об устойчивости мужского гаметофита, наряду с данными полученными методами классической селекции, может способствовать повышению эффективности скрининга перспективных генотипов, проведена оценка используемых гибридных комбинаций по термоустойчивости. Как показали полученные результаты, наиболее высокие значения этого признака (45,6...69,5\%) отмечены у 3-х гибридов F5: ВенецхЭльвира, М.Г. х Михаела, Венец х Михаела, тогда как самый низкий уровень устойчивости $(23,2 \%)$ обнаружили пыльцевые зерна гибрида F5 М.Г. х Эльвира. Следует отметить, что в составе изученных генотипов отмечены 4 гибридные комбинации F5 (М.Г. х Томиш, М.Г. х Престиж, М.Г. х Юбиляр и Викторина х Михаела), пыльцевые зерна которых обнаружили средний уровень устойчивости - 37,8 ..42,4\% (табл.). 
В результате сравнения генотипов по устойчивости длины пыльцевых трубок выявлены высокие значения этого признака, которые в зависимости от генотипа варьировали в пределах 64,6...83,8\%, что подтверждает высокую скорость их роста даже после прогревания (табл.).

\section{Выводы}

Действие высокой температуры оказывает существенное влияние на вариабельность признаков мужского гаметофита гибридов томата. Выявлено, что у изученных гибридных комбинаций температурный фактор и генотип являются главными источниками изменчивости признаков мужского гаметофита в условиях повышенной температуры. В результате проведенных экспериментов выделены три наиболее термоустойчивых генотипа томата.

Исследования проведены в рамках Государственной Программы 20.80009.7007.04 «Биотехнологии и генетические способы выявления, сохранения и использования агробиоразнообразия», финансируемой Национальным Агентством по Исследованиям и Развитию Республики Молдова.

\section{Литература}

1. PAUPIÈRE, M.J., VAN HAPEREN, P., RIEU, I. et al. Screening for pollen tolerance to high temperatures in tomato. Euphytica, 2017, vol. 213, 130.

2. DRIEDONKS, N., WOLTERS-ARTS, M., HUBER, H., DE BOER, G.-J., VRIEZEN, W., MARIANI, C., RIEU I. Exploring the natural variation for reproductive thermotolerance in wild tomato species. Euphytica, 2018,vol. 214, Article number: 67.

3. HANSON, P.M., CHEN, J-T., KUO, G. Gene action and heritability of high-temperature fruit set in tomato line CL5915. HortScience, 2002, 37:172-175.

4. HAZRA, P, ANSARY, S., DUTTA, A., BALACHEVA, E., ATANASSOVA, B. Breeding tomato tolerant to high temperature stress. Acta Hort., 2009. 830. 241-248.

5. AYENAN, M., DANQUAH, A., HANSON, P., AMPOMAH-DWAMENA, C., SODEDJI, F. Accelerating breeding for heat tolerance in tomato (Solanum lycopersicum L.): An integrated approach. Agronomy, 2019, 9 (11), 720.

6. ЮРЛОВА, Е.В. Оценка томатов на устойчивость к нерегулируемым абиотическим факторам. Сиб. Вестник с-х. наук. 2006. №2. С.27-36.

7. FIRON, N.; SHAKED, R.; PEET, M.M.; PHARR, D.M.; ZAMSKI, E.; ROSENFELD, K.; ALTHAN, L.; PRESSMAN, E. Pollen grains of heat tolerant tomato cultivars retain higher carbohydrate concentration under heat stress conditions.Sci. Hortic. 2006, 109, 212-217.

8. XU, J.; WOLTERS-ARTS, M.; MARIANI, C., HUBER, H. RIEU, I. Heat stress affects vegetative and reproductive performance and trait correlations in tomato (Solanum lycopersicum). Euphytica, 2017, 213, $1-12$. 